\title{
PROTOTIPE MOBILE MAIN CONTROL FIRE ALARM UNTUK AREA RISIKO KEBAKARAN TINGKAT SEDANG
}

\author{
Ahmad Rizqi Saifuddin ${ }^{1}$, \\ Jurusan Teknik Elektro, Fakultas Teknologi Industri, Universitas Trisakti \\ Email: ahmaduun@gmail.com \\ Kiki Prawiroredjo ${ }^{1}$ \\ Jurusan Teknik Elektro, Fakultas Teknologi Industri, Universitas Trisakti \\ Email: kiki.prawiroredjo@trisakti.ac.id \\ Susan Sulaiman ${ }^{1}$ \\ Jurusan Teknik Elektro, Fakultas Teknologi Industri, Universitas Trisakti \\ Email: susan@trisakti.ac.id
}

\begin{abstract}
Prototype of Mobile Main Control Fire Alarm (MCFA) for Medium Fire Risk Areas as at automotive component production department in-service part room, is an active fire protection system that can be a solution to simplify and speed up the time of fire fighting and securing activity during fire accident using daily used media, that is smartphones. In this research, a system was created to detect fires due to smoke and flames, notify firefighters, show the real situation via a smartphone, and activate the fire extinguisher. The system uses an MQ-2 sensor as a smoke detector and a KY-026 sensor as a flame detector connected with Node MCU as the main component completed by an IP camera to monitor the actual condition of fire location. The system consists of an alarm that indicates a fire, fire location information, and a display of the actual conditions from a camera integrated into the MCFA mobile application. The application can control a relay to turn on/off a pump as a fire extinguisher works when the user wants it. The value of smoke concentrations used as an indicator of the occurrence of a fire is when it exceeds 2112 ppm, while the value of light intensity used is when it exceeds 35 lux. Result data of acquisition and monitoring are sent to an Android smartphone using a Wi-Fi network that can be accessed in real-time. From the test results, it is found that the farthest distance that a smoke detector can detect is $25 \mathrm{~cm}$ while the flame detector is $65 \mathrm{~cm}$. The average time needed by the system from a notification time until the start extinguishes fire is 3,019 minutes.
\end{abstract}

Keywords: MCFA; smoke detector; flame detector; Node MCU; IP camera; Wi-Fi

\begin{abstract}
ABSTRAK:Prototipe Mobile Main Control Fire Alarm (MCFA) untuk Area Risiko Kebakaran Tingkat Sedang seperti di bagian produksi komponen otomotif di ruang service part, merupakan sistem proteksi kebakaran aktif yang dapat menjadi solusi untuk mempermudah dan mempercepat waktu tindakan pemadaman dan pengamanan saat terjadinya kebakaran menggunakan media yang digunakan sehari-hari, yaitu smartphone. Pada penelitian ini dibuat sebuah sistem yang dapat mendeteksi kebakaran karena asap dan nyala api, memberi notifikasi kepada petugas kebakaran, memperlihatkan keadaan riil melalui smartphone dan mengaktifkan pemadam kebakaran. Sistem terdiri dari sensor MQ-2 sebagai detektor asap dan sensor KY-026 sebagai detektor nyala api yang dihubungkan dengan Node MCU sebagai komponen utama dilengkapi kamera IP untuk memantau kondisi aktual lokasi kebakaran. Sistem terdiri dari alarm indikasi kebakaran, informasi lokasi kebakaran, dan tampilan kondisi aktual dari kamera yang terintegrasi pada aplikasi mobile MCFA. Aplikasi tersebut juga dapat menginstruksikan relay untuk on/off pompa sebagai alat pemadam api bekerja ketika user menghendakinya. Nilai kadar kepekatan asap yang digunakan sebagai indikator terjadinya kebakaran adalah apabila sudah melebihi 2112 ppm, sedangkan nilai intensitas cahaya yang digunakan adalah apabila sudah melebihi 35 lux. Data hasil akuisisi dan pemantauan dikirim ke smartphone Android menggunakan jaringan Wi-Fi yang dapat diakses secara realtime. Dari hasil pengujian didapat bahwa jarak terjauh yang dapat dideteksi sensor asap yaitu $25 \mathrm{~cm}$ sedangkan flame detector $65 \mathrm{~cm}$. Rata-rata waktu yang dibutuhkan sistem dari notifikasi sampai mulai memadamkan api adalah 3,019 menit.
\end{abstract}

Kata kunci: MCFA; detektor asap; detektor nyala api; Node MCU; Kamera IP; Wi-Fi

\section{PENDAHULUAN}

$\mathrm{B}$ erdasarkan persyaratan teknis sistem proteksi aktif pada bangunan gedung dan lingkungan, salah satu peralatan penting yang perlu dimiliki oleh setiap kegiatan industri sebagai sistem proteksi kebakaran adalah MCFA (Main Control Fire Alarm) yang lengkap dan menyediakan fungsi untuk inisiasi sebagai sinyal input kepada sistem, fungsi notifikasi untuk memberitahukan bahwa tindakan manusia diperlukan dalam menanggapi sebuah kondisi khusus, dan fungsi pengendalian peralatan bangunan gedung guna meningkatkan perlindungan keselamatan jiwa [1].

Contoh penerapan sistem proteksi aktif ada di lingkungan kerja bagian produksi komponen otomotif. Keselamatan dan kesehatan kerja (K3) merupakan faktor paling penting yang menjadi perhatian perusahaan, oleh karena itu fasilitas penunjang K3 khususnya pemadam kebakaran sudah lengkap dan terpelihara dengan baik.

\footnotetext{
${ }^{1}$ Jurusan Teknik Elektro Fakultas Teknologi Industri Universitas Trisakti
} 
Ada 3 jenis risiko kebakaran yang digunakan pada suatu industri otomotif. Untuk area dengan risiko kebakaran berat sudah dilengkapi sistem MCFA dengan APAR otomatis dan fasilitas hidran. Sedangkan untuk area terbanyak yaitu risiko kebakaran tingkat sedang dan ringan dilengkapi sistem MCFA dengan APAR yang difungsikan secara manual oleh petugas K3. Dari sistem tersebut masih terdapat beberapa kekurangan khususnya pada area risiko kebakaran tingkat sedang. Pertama, waktu yang diperlukan untuk memulai proses pemadaman api sekitar 30 menit. Kedua, timbul kerugian dalam jumlah yang banyak dari segi moril dan materiil apabila terjadi false alarm (bentuk alarm yang aktif karena menangkap sinyal selain sinyal api pemicu kebakaran).

Sistem mobile MCFA yang dirancang di sini adalah sistem untuk area risiko kebakaran tingkat sedang di ruangan service part yang dapat menyajikan data secara realtime pada media yang digunakan sehari-hari dan bersifat portable yaitu smartphone Android. Pembacaan sensor diproses oleh Node MCU dan dikirimkan menggunakan jaringan Wi-Fi bersamaan dengan hasil pemantauan kamera. Data yang dihasilkan adalah alarm indikasi kebakaran, informasi lokasi kebakaran, dan tampilan kondisi aktual dari kamera pada sebuah aplikasi Android yang dilengkapi sistem kendali alat pemadam api yang diperlukan untuk penanganan kebakaran.

\section{KAJIAN PUSTAKA}

Pada penelitian Sri Safrina Dewi dkk, data yang dikirimkan oleh detektor kebakaran secara jarak jauh akan diterima oleh modul GSM Wavecom dan diolah pada komputer PC. Pengolahan data diproses pada database mySQL sebagai database system management dengan menggunakan tabel Gammu dan tabel lokasi. Prototipe sistem informasi monitoring kebakaran dibangun dalam dua sistem yaitu sistem deteksi kebakaran dan sistem informasi lokasi kebakaran yang berbasis Google Maps. Kedua sistem menghasilkan informasi data lokasi terjadinya kebakaran beserta data kondisi adanya asap dan suhu/temperatur [2].

Pada penelitian Ichsan Ramadhan dkk, sensor gas akan mengeluarkan data sebagai masukan yang akan di proses oleh NodeMCU untuk mengaktifkan aktuator berupa buzzer. Data tersebut kemudian dikirimkan ke web server berjenis free hosting yang dapat diakses oleh pengguna dengan smartphone yang berbasis Android. Sensor MQ-2 sebagai pendeteksi kebocoran gas mampu mendeteksi kebocoran gas dengan media korek gas dan dapat menyalakan buzzer pada prototipe rumah dengan jarak uji $0 \mathrm{~cm}, 5 \mathrm{~cm}$, dan $10 \mathrm{~cm} \mathrm{[3].}$

Pada penelitian Maulana Hasan dkk, sistem menggunakan tiga sensor yaitu sensor api KY-026, sensor suhu DS18B20, dan sensor gas MQ-7. Sistem ini memberikan tiga level peringatan dini, yaitu 'normal', 'warning' dan 'bahaya'. Level peringatan ini dapat disampaikan ke aplikasi Android melalui jalur Bluetooth dengan jarak maksimum 20 meter di tempat terbuka dan jarak maksimum 10 meter di tempat tertutup [4].

Berdasarkan beberapa penelitian terdahulu dirancang sebuah prototipe dengan fitur-fitur tambahan pada sistem proteksi kebakaran antara lain, tampilan kondisi aktual area kebakaran dengan kamera dan alat pemadam api untuk penanganan kebakaran. Semua fitur terintegrasi dalam suatu aplikasi Android yang dapat bekerja sesuai dengan keinginan pengguna.

\section{Spesifikasi sistem}

\section{METODE PENELITIAN}

Spesifikasi sistem dirancang sesuai peraturan Menteri Pekerjaan Umum nomor 26/PRT/M/2008 tentang Persyaratan Teknis Sistem Proteksi Kebakaran pada Bangunan Gedung dan Lingkungan [1].

\section{Fitur tersedia}
a. Alarm indikasi kebakaran sebagai fungsi inisiasi.
b. Informasi lokasi kebakaran dan tampilan kondisi aktual kamera sebagai fungsi notifikasi.
c. Tombol instruksi pemadam api bekerja sebagai fungsi pengendalian.

\section{Waktu Pemadaman}

Berdasarkan peraturan, waktu tanggap pemadaman kebakaran tidak lebih dari 15 menit, maka dirancang suatu sistem proteksi yang dapat melakukan pemadaman kebakaran dalam waktu tidak lebih dari 3 menit, rinciannya terdapat pada Tabel 1. 
Tabel 1.Spesifikasi Waktu Pemadaman Sistem Mobile MCFA

\begin{tabular}{clc} 
No. & \multicolumn{1}{c}{ Aktifitas } & $\begin{array}{c}\text { Waktu yang } \\
\text { diperlukan (detik) }\end{array}$ \\
\hline 1 & $\begin{array}{l}\text { Sensor mendeteksi adanya api atau asap dan } \\
\text { mengirimkan informasi ke Android petugas K3 } \\
\text { Petugas K3 mengecek lokasi kebakaran melalui } \\
\text { aplikasi di Android }\end{array}$ & 20 \\
3 & $\begin{array}{l}\text { Petugas K3 mengidentifikasi kondisi aktual hasil } \\
\text { tangkapan kamera di aplikasi Android }\end{array}$ & 60 \\
4 & $\begin{array}{l}\text { Petugas K3 mengintruksikan pemadam api } \\
\text { bekerja melalui aplikasi Android }\end{array}$ & 10 \\
5 & $\begin{array}{l}\text { Pemadam api mulai bekerja } \\
\text { Total waktu yang diperlukan }\end{array}$ & 20 \\
\hline
\end{tabular}

\section{Rancangan Sistem}

Keseluruhan sistem dibagi menjadi dua blok yaitu rangkaian sensor asap sebagai prototipe Meeting Room dan rangkaian sensor flame sebagai prototipe Employee Facility, seperti dapat dilihat pada Gambar 1.

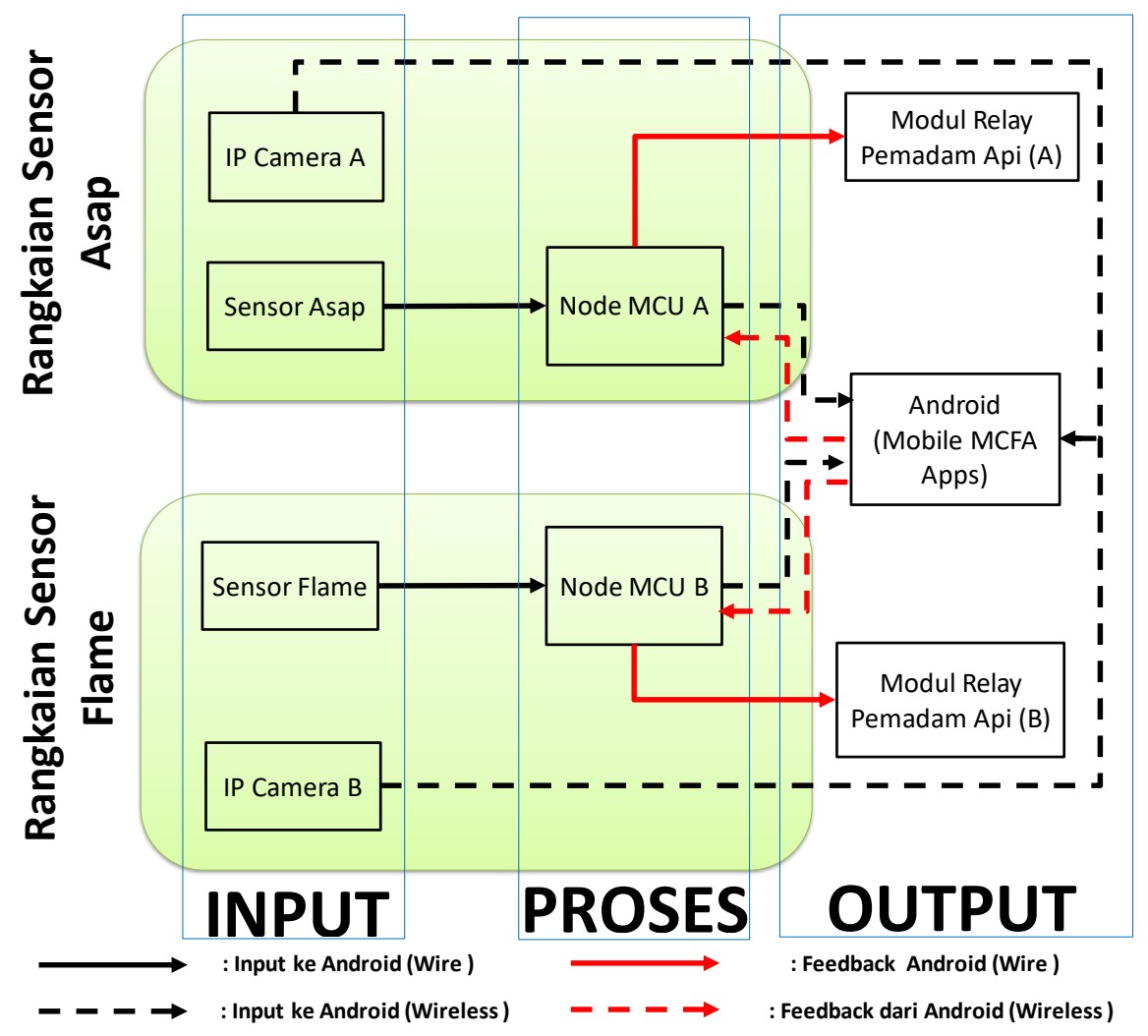

- Gambar 1. Diagram Blok Keseluruhan Rancangan Sistem

Sistem dibuat untuk memenuhi fungsi inisiasi, notifikasi dan pengendalian kebakaran yang dapat diakses dari output sistem yaitu mobile MCFA apps.

a. Blok Input

1. Sensor asap akan mendeteksi apabila ada kandungan asap yang abnormal di ruang meeting dan memberi input berupa tegangan ke Node MCU A.

2. Sensor flame akan mendeteksi apabila ada kandungan api di employee facility dan memberi input berupa tegangan ke Node MCU B.

3. IP camera memantau keadaan aktual lokasi kejadian secara realtime dan terhubung langsung ke Android. 


\section{b. Blok Proses}

1. Modul Node MCU memproses data yang berasal dari sensor asap dikirimkan ke Android melalui jaringan Wi-Fi dari modul itu sendiri.

2. Data dari modul Node MCU berupa informasi kondisi sensor asap atau sensor flame on/off.

3. Node MCU juga menerima feedback dari Android apabila petugas K3 menekan tombol instruksi pemadam api bekerja.

\section{c. Blok Output Smartphone}

1. Aplikasi mobile MCFA menampilkan informasi berupa alarm indikasi kebakaran ketika kondisi sensor asap $O N$, lokasi kebakaran yang diperoleh dari informasi sensor yang sedang $O N$, dan video tampilan kondisi aktual lokasi kejadian dari IP camera.

2. Petugas K3 akan menekan tombol instruksi pemadam api bekerja apabila tampilan kondisi aktual memang benar terjadi kebakaran sehingga memberikan input ke Node MCU melalui jaringan Wi-Fi.

\section{d. Blok Output Pemadam Api}

Node MCU memberikan perintah untuk on/off relay sebagai input pompa pemadam api.

\section{Rancangan Perangkat Keras}

Perancangan perangkat keras pada rangkaian prototipe ruang meeting meliputi penentuan tempat meletakkan sensor asap MQ-2, modul Node MCU A, modul relay 5V A, pompa pemadam api A, serta catu daya yang dibutuhkan. Pada Gambar 2 (a), adalah rangkaian skematik dari prototipe ruang meeting dan wiring yang dibuat. Komponen lainnya yaitu IP camera dan Android terkoneksi dengan rangkaian menggunakan metode wireless.

Sama halnya dengan perancangan perangkat keras pada rangkaian prototipe employee facility dapat dilihat pada Gambar 2 (b), meliputi penentuan tempat meletakkan sensor flame, modul Node MCU $\mathrm{B}$, modul relay $5 \mathrm{~V}$ B, pompa pemadam api B, serta catu daya yang dibutuhkan. IP camera dan Android pun terkoneksi dengan rangkaian menggunakan metode wireless.

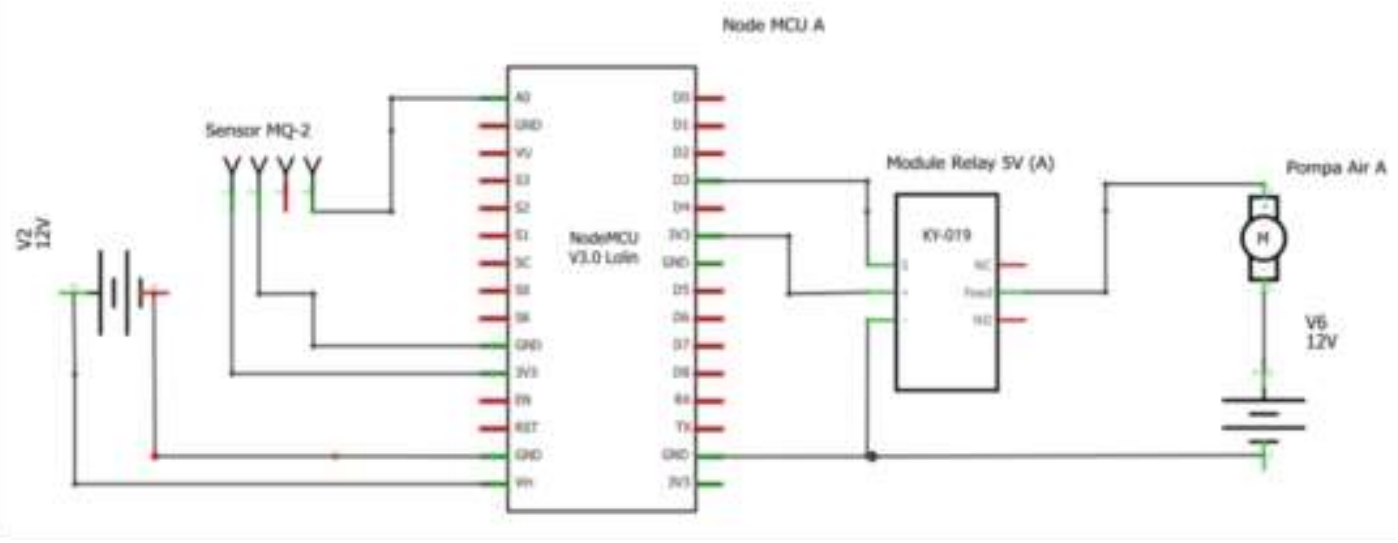

(a)

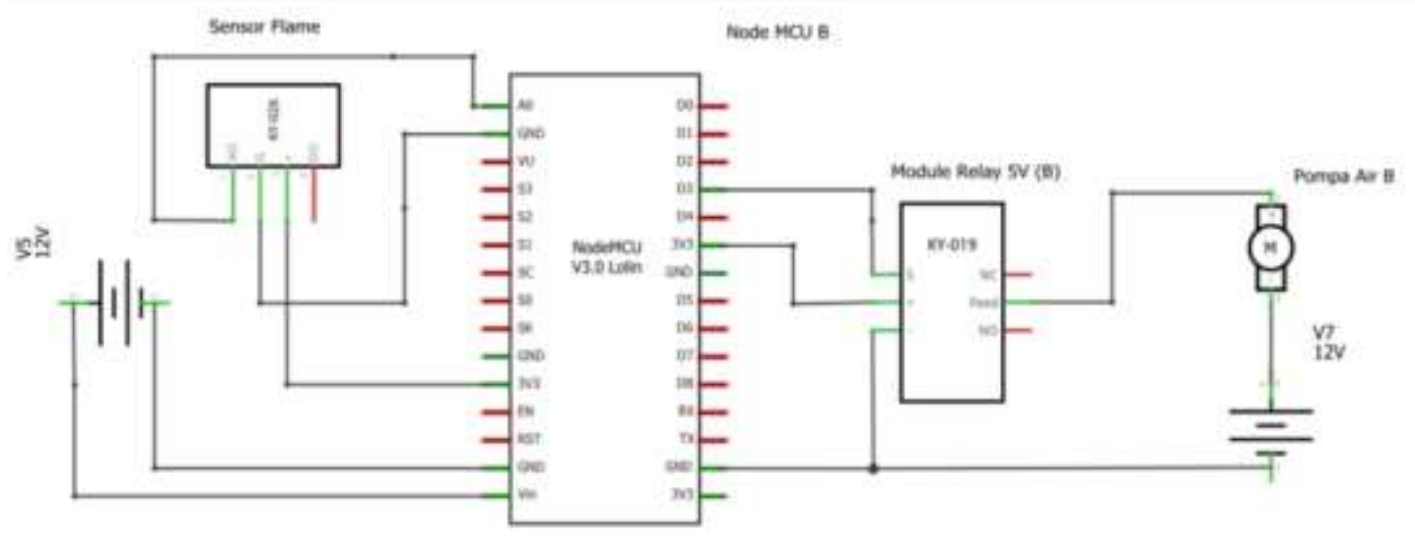

(b)

- Gambar 2. (a) Skematik Rangkaian Prototipe Ruang Meeting

(b) Skematik Rangkaian Prototipe Employee Facility 
Layout rangkaian elektronik berupa modul sensor, Node MCU, modul relay beserta adaptor $12 \mathrm{~V}$ sebagai prototipe ruang Meeting dan Employee Facility dibuat dalam ruangan yang terpisah dengan pompa wiper sebagai alat pemadam api. Pompa wiper dibuat menempel dengan tangki air cadangan pemadam api.

\section{Rancangan Perangkat Lunak}

Digunakan dua jenis software yaitu Arduino IDE sebagai software untuk memprogram Node MCU, dan MIT App Inventor yang digunakan untuk mendesain aplikasi Android.

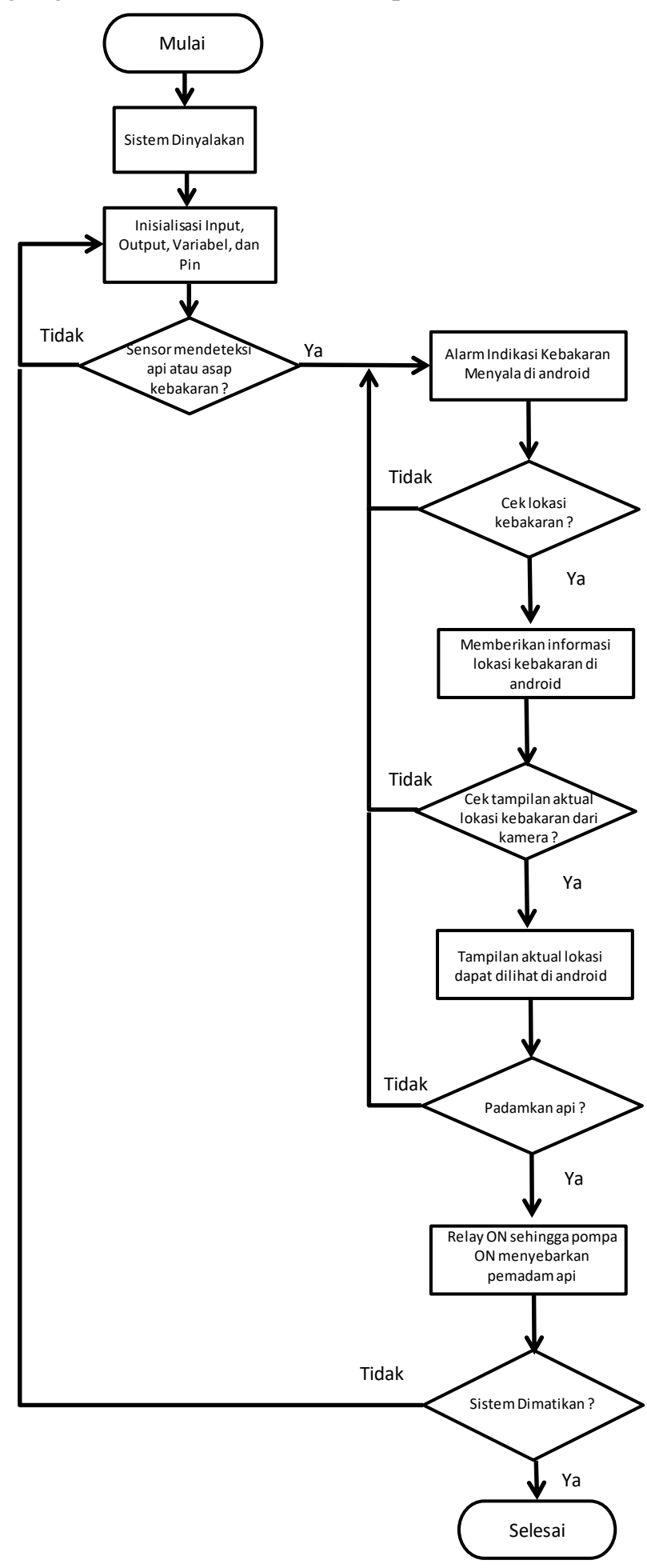

- Gambar 3. Diagram Alir Kerja Sistem

Pada Gambar 3 dapat dilihat diagram alir kerja sistem prototipe mobile main MCFA. Saat sistem diaktifkan setiap sensor akan bekerja dan membaca keadaan secara realtime. Apabila sensor asap MQ- 
2 mendeteksi kandungan asap yang abnormal maka sensor akan mengirimkan data ke Node MCU A, sama halnya dengan sensor flame apabila mendeteksi adanya api maka sensor akan mengirimkan data ke Node MCU B. Node MCU mengirimkan informasi dari tiap sensor ke output Android menggunakan platform aplikasi mobile MCFA. Aplikasi mobile MCFA memberikan notifikasi berupa alarm kebakaran. Saat alarm kebakaran dalam kondisi ON, petugas K3 dapat memilih button yang menginstruksikan aplikasi memberikan informasi lokasi kebakaran yang terdeteksi di area sensor MQ2 atau sensor flame. Setelah petugas K3 mengetahui informasi lokasi kebakaran, petugas K3 dapat memantau kondisi aktual kebakaran pada lokasi yang sudah diketahui. Apabila buttonmonitoring camera sudah dipilih, IP camera menyala dan memberikan informasi berupa kondisi aktual lokasi kebakaran yang dikirimkan ke Android. Apabila setelah diperiksa oleh petugas K3 dan hasilnya benar terjadi kebakaran, petugas K3 dapat menekan button pada Android yang menginstruksikan relay ON dan menyalakan pompa yang dapat melakukan pemadaman kebakaran.

\section{HASIL DAN PEMBAHASAN}

Proses pengujian prototipe mobile MCFA untuk area risiko kebakaran tingkat sedang di ruangan service part dilakukan sesuai dengan diagram alir kerja sistem untuk rangkaian prototipe ruang meeting dan rangkaian prototipe employee facility. Pengujian karakteristik sensor dilakukan dengan mengambilan data dari sensor yang diproses oleh NodeMCU dan pengujian aplikasi yang telah dibuat pada smartphone berbasis Android dilakukan dengan mencoba aplikasi tersebut. Bagian-bagian yang diuji adalah modul sensor asap MQ-2, modul sensor flame KY-026, IP camera, rangkaian pemadam api (relay dan pompa), notifikasi yang ditampilkan pada smartphone, serta pengujian keseluruhan kinerja sistem meliputi uji waktu penerimaan data sampai ke pengguna smartphone dalam hal ini petugas K3 dan uji rentang jarak yang optimal untuk pengiriman dan penerimaan data. Percobaan pengiriman data dilakukan menggunakan jaringan Wi-Fi yang bersumber dari NodeMCU.

Pada Gambar 4 memperlihatkan rangkaian lengkap dari modul sensor asap dan Gambar 5 memperlihatkan rangkaian lengkap dari modul sensor flame.
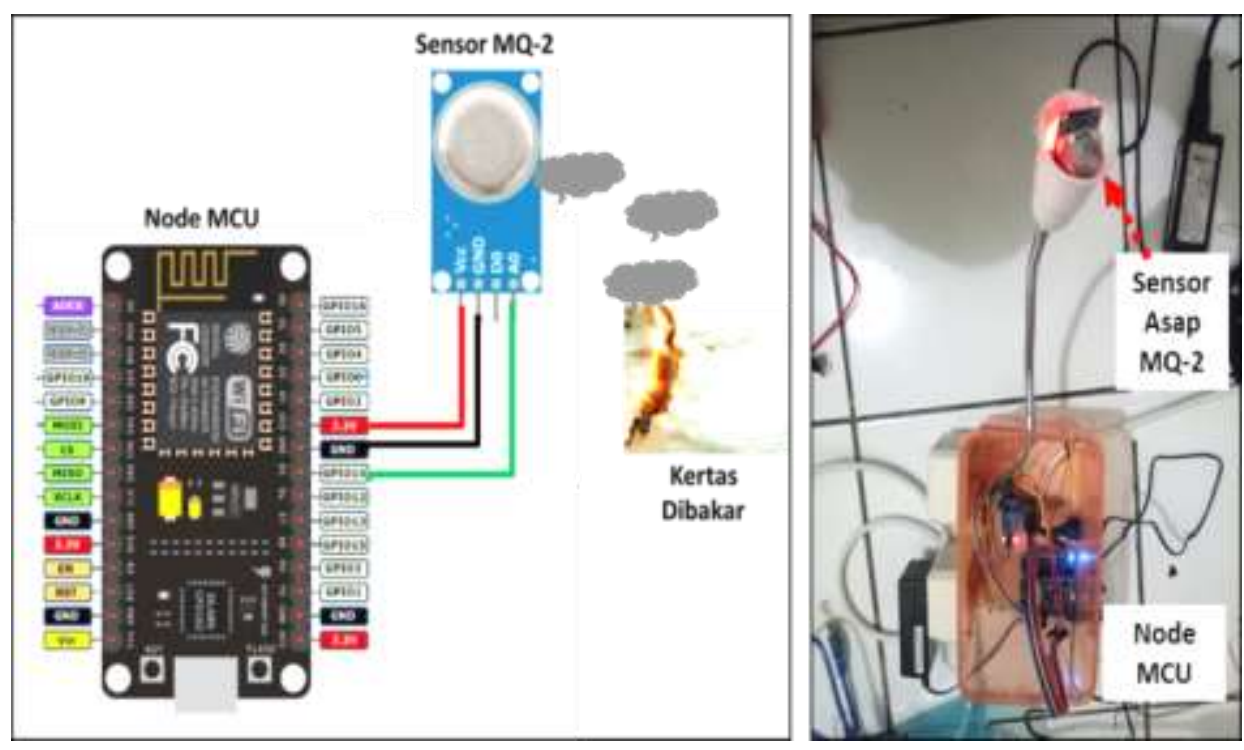

- Gambar 4. Modul Sensor Asap

Pada pengujian modul sensor asap digunakan kertas yang dibakar sehingga menghasilkan asap untuk dideteksi oleh sensor MQ-2. 

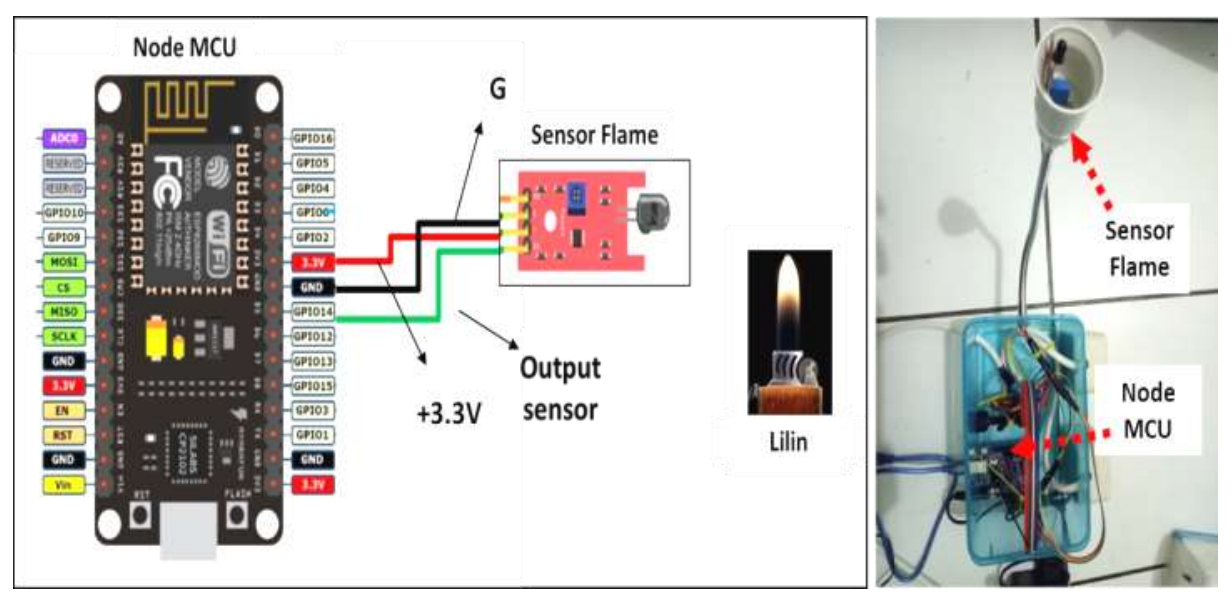

- Gambar 5. Modul Sensor Flame

Pada pengujian modul sensor flame digunakan lilin yang menyala sehingga menghasilkan nyala api untuk dideteksi oleh sensor KY-026.

\section{Hasil Pengujian Modul Sensor Asap MQ -2}

Karakteristik sensor asap dapat diketahui dari hasil 16 kali pengukuran respon sensor yang menghasilkan nilai ADC pada aplikasi ARDUINO IDE dan nilai ppm komponen yang diukur menggunakan ppm meter. Pengukuran dilakukan pada jarak $5 \mathrm{~cm}$ sampai dengan $40 \mathrm{~cm}$ antara sensor dan sumber asap dengan perbedaan jarak $5 \mathrm{~cm}$ untuk tiap titik pengukuran dan tiap titik pengukuran diuji dua kali. Gambar 6 menunjukkan karakteristik respon sensor asap antara jarak terhadap bit ADC yang dihasilkan, sedangkan Gambar 7 menunjukkan karakteristik respon sensor asap antara jarak terhadap nilai ppm komponen asap.

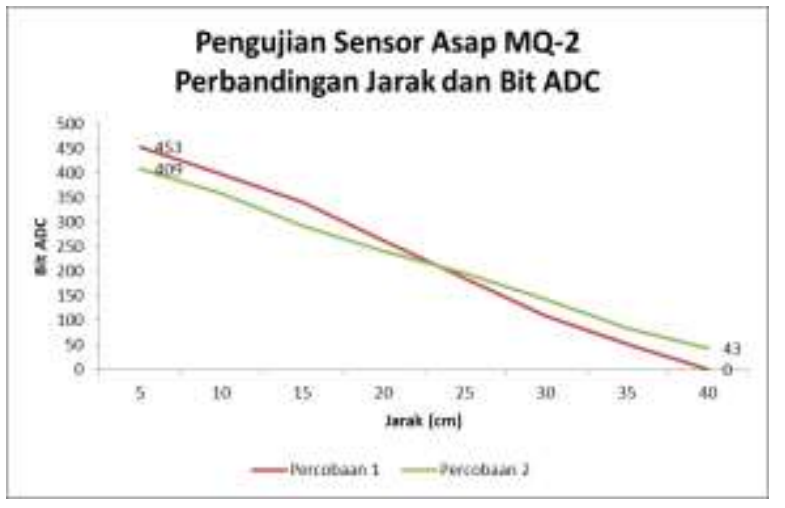

- Gambar 6. Grafik Jarak Terhadap Nilai ADC

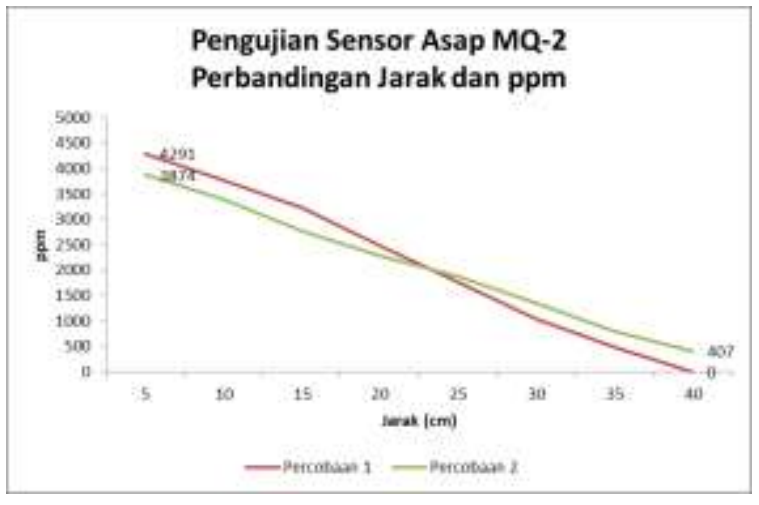

- Gambar 7. Grafik Jarak Terhadap Kadar ppm Komponen Asap

Nilai ADC rata-rata dari 16 kali pengukuran percobaan yaitu sebesar 223 sedangkan nilai kadar asap rata-rata dari 16 kali pengukuran yaitu 2112 ppm diambil sebagai acuan dalam menentukan kerja sistem dimana jarak antara sensor dan asap adalah $25 \mathrm{~cm}$ sesuai Gambar 5. Apabila sensor membaca nilai ADC lebih besar dari 223 atau kadar kepekatan asap lebih dari 2112 ppm maka alarm kebakaran akan menyala dan aplikasi mobile MCFA akan memberitahukan informasi tersebut kepada petugas K3

\section{Hasil Pengujian Modul Sensor Flame KY-026}

Karakteristik sensor flame dapat diketahui dari hasil 25 kali pengukuran tegangan yang dihasilkan pada Node MCU dan intensitas cahaya yang diukur menggunakan lux meter. Pengukuran dilakukan pada jarak $5 \mathrm{~cm}$ sampai dengan $125 \mathrm{~cm}$ antara sensor dan sumber nyala api dengan perbedaan jarak $5 \mathrm{~cm}$ untuk tiap titik pengukuran dan tiap titik pengukuran diuji dua kali. Gambar 8 menunjukkan grafik perbandingan jarak, tegangan, dan intensitas cahaya pada pengujian pertama, sedangkan Gambar 9 menunjukkan grafik perbandingan jarak, tegangan, dan intensitas cahaya pada pengujian kedua. 


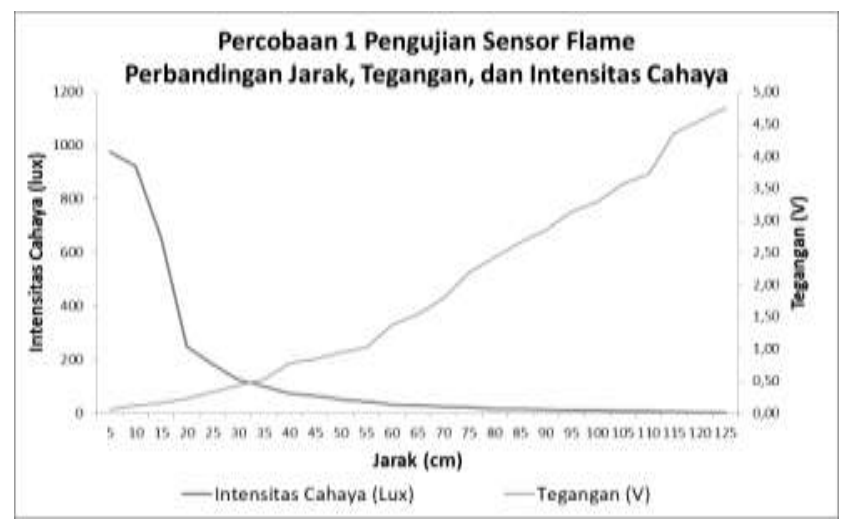

- Gambar 8. Grafik Perbandingan Antara Jarak, Tegangan dan Intensitas Cahaya Pengujian Pertama

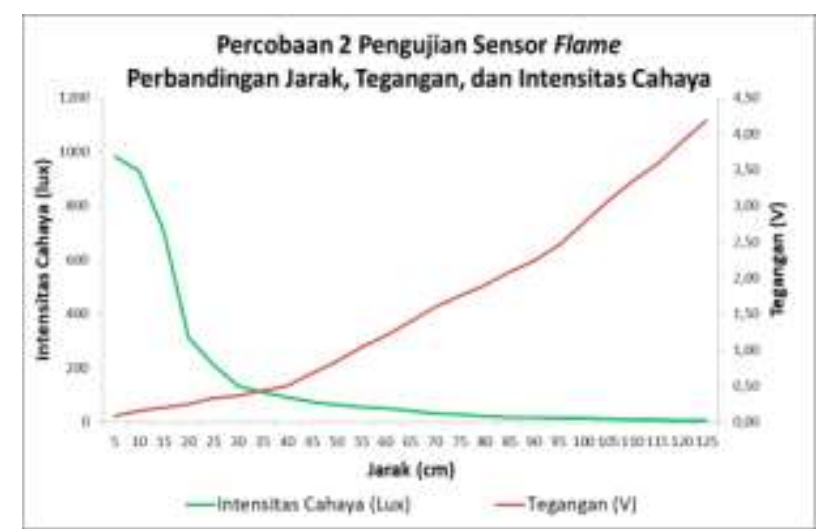

- Gambar 9. Grafik Perbandingan Antara Jarak, Tegangan dan Intensitas Cahaya Pengujian Kedua

Pada Gambar 8 dan 9 dapat dilihat apabila sumber api berjarak paling dekat terhadap sensor, maka nilai tegangan output sensor berada pada titik terendah yang berarti api dalam kondisi besar atau menyala sangat terang. Sebaliknya jika sumber api berada pada jarak yang jauh terhadap sensor, maka nilai tegangan output sensor akan meningkat. Sensor flame KY-026 dapat menerima input berupa nyala api dengan baik sampai dengan jarak $70 \mathrm{~cm}$ dengan nilai tegangan sebesar 1,62 volt.

Dari hasil uji pembacaan sensor terlihat bahwa sensor flame mampu mendeteksi nyala api dari jarak $5 \mathrm{~cm}$ hingga $125 \mathrm{~cm}$. Untuk kebutuhan algoritma pemrograman, nilai yang ditetapkan saat terdeteksi api adalah pada saat nilai ADC sebesar 300 yang dikonversikan ke nilai tegangan menjadi 1,5 volt dengan jarak antara sensor dengan nyala api sejauh $65 \mathrm{~cm}$ sesuai Gambar 6 dan Gambar 7. Nilai intensitas cahaya yang dipakai untuk algoritma pemrograman sebagai acuan nilai deteksi nyala api adalah sebesar 35 lux karena masih sesuai dengan karakteristik sensor dan meminimalisir kesalahan pembacaan sensor. Jika nilai intensitas cahaya yang dihasilkan lebih dari 35 lux, maka sensor flame mendeteksi adanya nyala api sehingga alarm kebakaran akan menyala dan aplikasi mobile MCFA akan memberitahu informasi tersebut kepada pengguna.

\section{Hasil Pengujian Rangkaian Pemadam Api}

Diketahui berdasarkan hasil pengujian, karakteristik relay dapat menjalankan fungsi logika dalam sistem mikrokontroler. Saat output mikrokontroler berlogika 0 maka relay akan $O F F$ sehingga dapat mematikan aktuator, sementara saat output mikrokontroler berlogika 1 maka relay akan $O N$ sehingga dapat menyalakan aktuator.

Rangkaian pemadam api yang terdiri dari modul relay $5 \mathrm{~V}$ dan pompa wiper dapat berfungsi seperti yang direncanakan. Modul relay $5 \mathrm{~V}$ menerjemahkan fungsi logika keluaran Node MCU (mikrokontroler) jika berlogika 1 maka pompa wiper dapat mengeluarkan air dengan tekanan tinggi untuk memadamkan api.

\section{Hasil Pengujian IP Camera}

Berdasarkan hasil pengujian untuk memeriksa kemampuan kinerja IP camera didapat hasil bahwa kamera dapat mengambil gambar dan video secara realtime sehingga dapat langsung dipantau melalui smartphone yang dikoneksikan menggunakan jaringan Wi-Fi. Pengiriman gambar dan video dari kamera ke smartphone cocok menggunakan berbagai sumber jaringan Wi-Fi dengan IP address yang berbeda-beda khususnya dari Node MCU yang akan digunakan sebagai sumber Wi-Fi pada keseluruhan sistem.

\section{Hasil Pengujian Keseluruhan Sistem}

Gambar 10 memperlihatkan layar utama aplikasi mobile MCFA, sedangkan Gambar 11 memperlihatkan aplikasi memberikan notifikasi kepada petugas K3 saat terjadi kebakaran. 


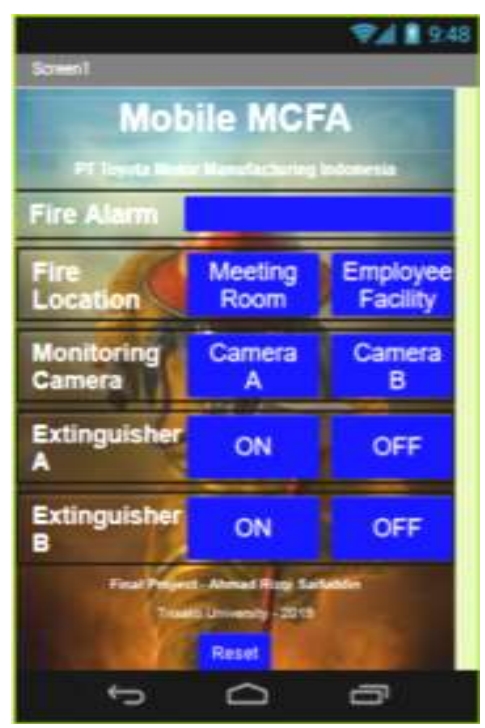

- Gambar 10. Layar Utama Mobile MCFA

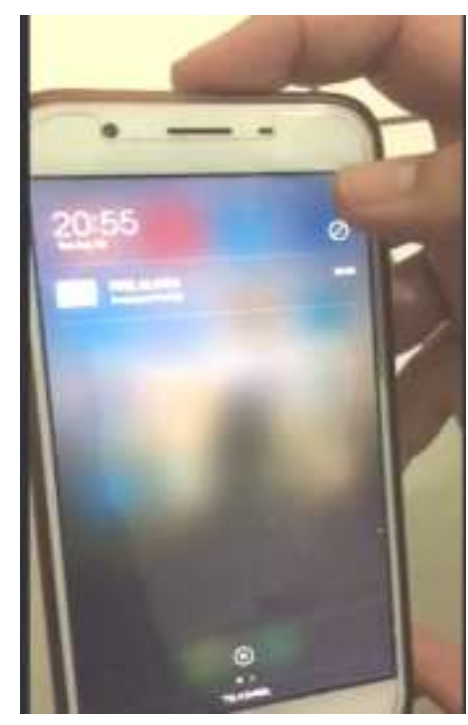

- Gambar 11. Notifikasi Kebakaran

Pada layar utama terdapat button berwarna biru disebelah kanan Fire Alarm yang akan berubah menjadi merah jika sensor asap atau sensor flame mendeteksi ada kebakaran. Fire Location menunjukkan lokasi terjadinya kebakaran yaitu di Meeting Room atau di Employee Facility. Button pada Monitoring Camera apabila disentuh akan memperlihatkan keadaan di ruang yang diinformasikan terjadi kebakaran yaitu Camera A untuk Meeting Room dan Camera B untuk Employee Facility. Button pada Extinguisher A dan B apabila disentuh akan mengaktifkan atau mematikan kerja rangkaian pemadam kebakaran di Meeting Room atau Employee Facility.

Gambar 12 memperlihatkan notifikasi kebakaran bersamaan dengan bunyi alarm pada smartphone apabila sensor mendeteksi ada kebakaran. Apabila layar smartphone disentuh maka akan menampilkan layar utama Mobile MCFA dengan perubahan warna indikator Fire Alarm dan lokasi kebakaran menjadi merah seperti terlihat pada Gambar 12.

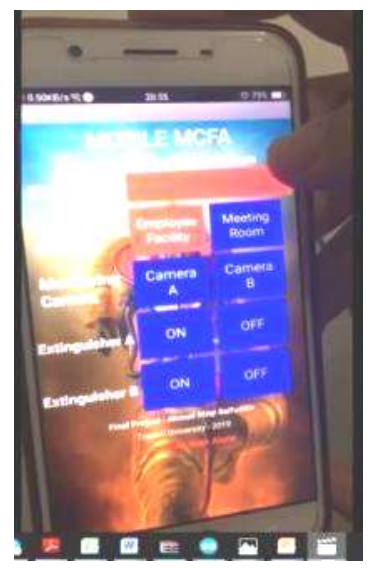

- Gambar 12. Indikasi Alarm Kebakaran Lokasi Kebakaran

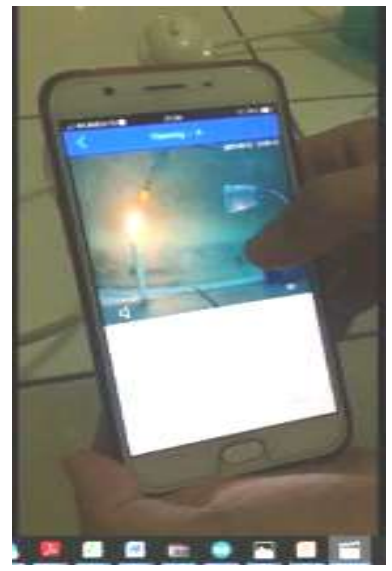

- Gambar 13. Tampilan Kondisi dan Informasi Aktual Kamera

Tampilan kondisi aktual kamera dapat dilihat secara realtime melalui smartphone apabila button Camera A disentuh seperti dapat dilihat pada Gambar 13. 


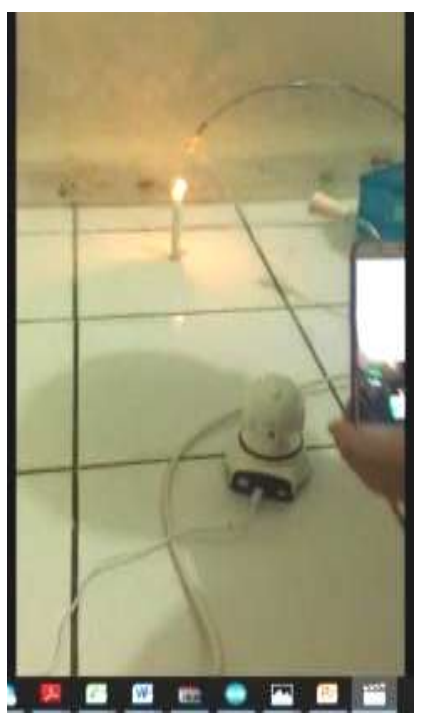

- Gambar 14. Pemadam Api Bekerja

Apabila kondisi aktual menunjukkan terjadinya kebakaran, maka petugas K3 akan menginstruksikan pemadam api bekerja dengan menyentuh button dengan tulisan ON di sebelah kanan Extinguisher A sehingga pemadam api bekerja seperti yang dapat dilihat pada Gambar 14.

Hasil pengujian secara keseluruhan pada Ruang Meeting dengan jarak sensor yang bervariasi terhadap asap diperlihatkan pada Tabel 2, sedangkan pengujian secara keseluruhan pada ruang Employee Facility dengan jarak sensor yang bervariasi terhadap flame diperlihatkan pada Tabel 3.

- Tabel 2. Hasil Pengujian Secara Keseluruhan di Ruang Meeting

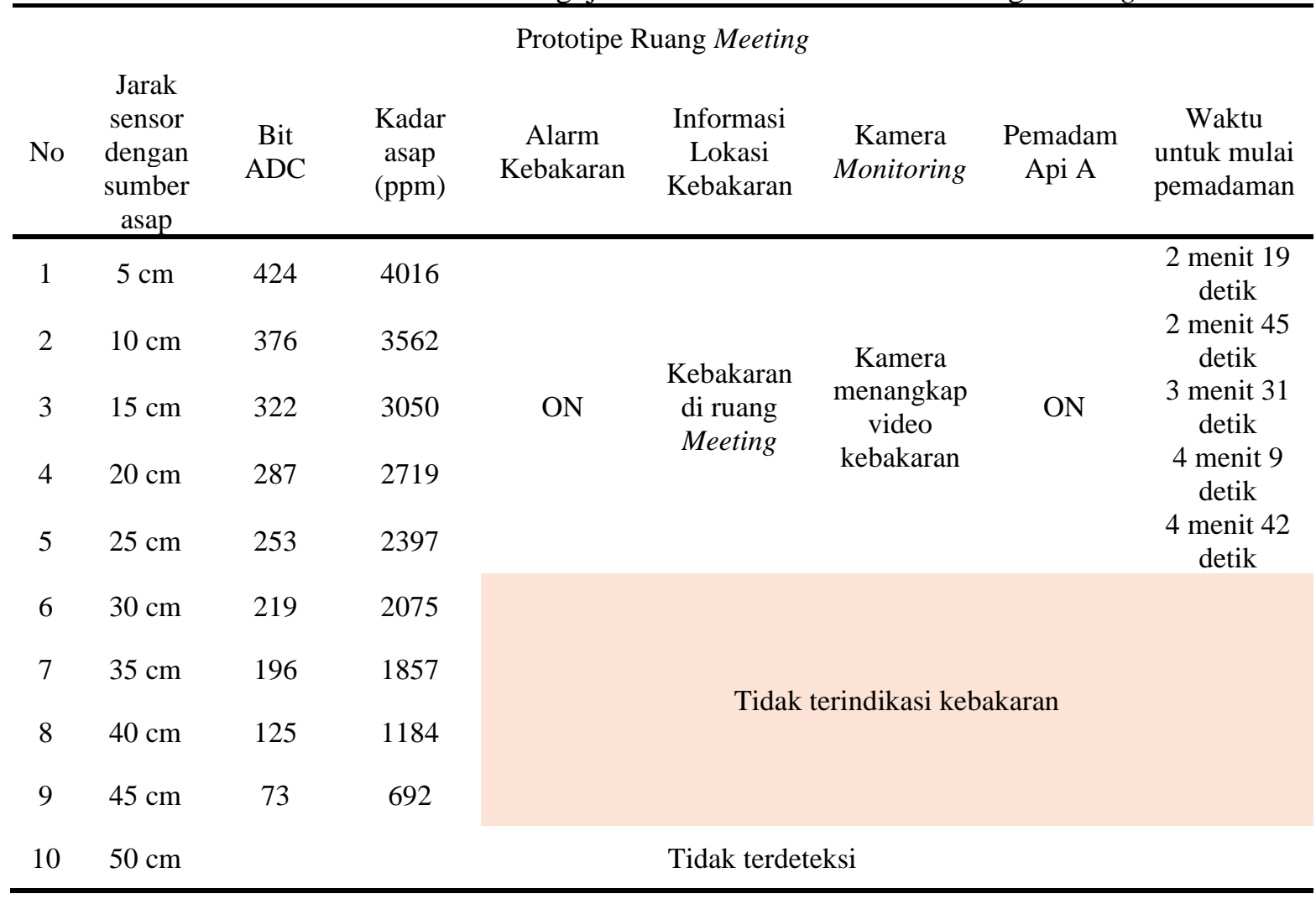

Dari hasil pengujiaan di Ruang Meeting dapat dilihat bahwa pada jarak $30 \mathrm{~cm}$ sensor asap tidak dapat mendeteksi lagi adanya asap dimana kadar asap sudah berada di bawah batas minimum 2112 ppm. Ratarata waktu dimulainya pemadaman kebakaran dari waktu adanya alarm kebakaran adalah 3 menit 29 detik. 
- Tabel 3.Pengujian Secara Keseluruhan di Ruang Employee Facility

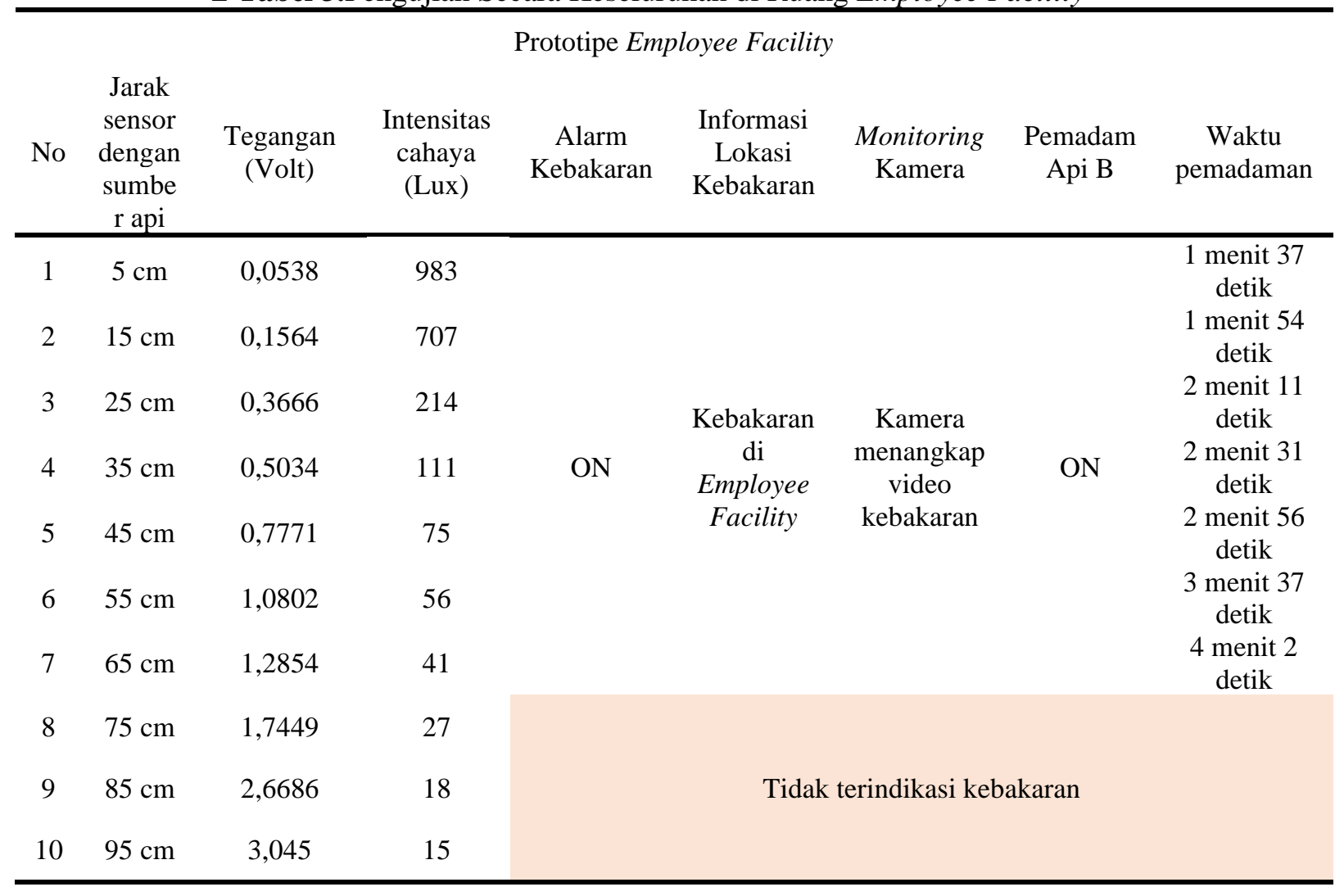

Dari hasil pengujiaan di Ruang Employee Facility dapat dilihat bahwa pada jarak $75 \mathrm{~cm}$ sensor flame tidak dapat mendeteksi lagi adanya flame dimana intensitas cahaya sudah berada di bawah batas minimum 35 lux. Rata-rata waktu dimulainya pemadaman kebakaran dari waktu adanya alarm kebakaran adalah 2 menit 41 detik.

\section{KESIMPULAN}

Setelah dibuat suatu prototipe mobile Main Control Fire Alarm untuk area risiko kebakaran tingkat sedang di bagian produksi komponen otomotif dan diuji maka disimpulkan dengan hasil sebagai berikut:

Aplikasi mobile MCFA memiliki fitur alarm indikasi kebakaran sebagai fungsi inisiasi, informasi lokasi kebakaran dan tampilan kondisi aktual kamera sebagai fungsi notifikasi, dan tombol instruksi pemadam api bekerja sebagai fungsi pengendalian yang keseluruhannya dapat bekerja dengan baik saat ada indikasi kebakaran.

Indikator terjadinya kebakaran bekerja apabila nilai kadar kepekatan asap sudah melebihi 2112 ppm atau apabila intensitas cahaya sudah melebihi 35 lux. Jarak terjauh yang dapat dideteksi sensor asap yaitu $25 \mathrm{~cm}$ sedangkan sensor flame $65 \mathrm{~cm}$.

Dengan adanya prototipe mobile main control fire alarm, PT TMMIN dapat menghemat waktu proses pemadaman api pada area dengan risiko kebakaran tingkat sedang, dimana dari notifikasi alarm sampai proses pemadaman semula membutuhkan waktu 30 menit, setelah adanya prototipe tersebut menjadi rata-rata 3 menit 29 detik untuk Ruang Meeting dan 2 menit 41 detik untuk ruang Employee Facility. Semakin jauh jarak sensor terhadap asap maupun flame semakin lama waktu yang dibutuhkan untuk memulai proses pemadaman kebakaran.

\section{Saran}

Untuk menjadi sebuah sistem yang dapat digunakan di lapangan perlu digunakan rangkaian penyesuaian untuk sensor yang mempunyai jarak deteksi yang lebih jauh dan rangkaian interface yang sesuai untuk mengaktifkan pompa pemadam kebakaran.

\section{REFERENSI}

[1] D. J. C. K. Departemen Pekerjaan Umum, Peraturan Menteri Pekerjaan Umum Nomor : 26/PRT/M/2008. Indonesia, 2008. 
[2] S. S. Dewi dan D. Satria, "Prototipe Sistem Informasi Monitoring Kebakaran Bangunan Berbasis Google Maps dan Modul GSM," J. Teknol. Inf. dan Komun., vol. 1, no. 1, pp. 33-38, 2017, doi: https://doi.org/10.35870/jtik.v1i1.

[3] I. Ramadhan dan K. PrawiroredRWjo, "Prototipe Otomatisasi Pengaman Rumah Berbasis Arduino dan Android," J. Ilm. Tek. Elektro - Univ. Trisakti, vol. 16, no. 1, pp. 71-86, 2018, doi: http://dx.doi.org/10.25105/jetri.v16i1.2843.

[4] M. Hasan dan A. R. A Tahtawi, "Detektor Dini Kebakaran Multisensor Terintegrasi Android Menggunakan Komunikasi Bluetooth,” J. Teknol. dan Sist. Komput., vol. 6, no. 2, pp. 64-70, 2018, doi: https://doi.org/10.14710/jtsiskom.6.2.2018.64-70 V. 